\title{
Girls should be Girls: The Impact of Child Marriage on Human Development
}

\author{
Raquel Rangel de Meireles Guimarães ${ }^{1}$ \\ Nayara Abreu Julião ${ }^{2}$ \\ Thaila Renata Teixeira Doria ${ }^{3}$
}

\begin{abstract}
Child marriage is a violation of Human Rights and an impediment to social and economic development, it is strongly rooted in gender inequality. In Brazil, this practice has a predominantly informal and consensual quality, they often involve adult men married to girls in early puberty. The objective of this study is to synthesize the literature on the impact of child marriage on the most diverse indicators of human development - such as education, labor market, health, fertility, violence and female empowerment. In summary, the literature reveals that child marriage has a negative impact on these indicators, and this corroborates the urge to eliminate this phenomenon, which will ensure women's right to a full economic and social life.
\end{abstract}

Keywords: Child marriage; Human Development; Public Policy.

\section{RESUMO}

O casamento infantil é uma violação dos Direitos Humanos e um impedimento para o desenvolvimento social e econômico, estando fortemente enraizado nas desigualdades de gênero. No Brasil, tal prática tem caráter, predominantemente, informal e consensual, envolvendo homens adultos e meninas na fase da infância e adolescência. O objetivo desse estudo é sintetizar a literatura sobre o impacto do casamento infantil sobre os mais diversos indicadores do Desenvolvimento Humano - tais como educação, mercado de trabalho, saúde, fecundidade, violência e empoderamento feminino. Em suma, a literatura revela que o casamento infantil impacta negativamente esses indicadores, o que reforça a necessidade de eliminação da prática, assegurando o direito das mulheres e meninas a uma vida econômica e social plena.

Palavras - Chave: Casamento infantil, Desenvolvimento Humano, Políticas Públicas.

\section{INTRODUCTION}

Child marriage is defined by UNICEF as a union, whether formal or informal, involving girls and/or boys younger than 18 years of age (UNICEF, 2017), being of little importance the fact that the earliest age for marriage with parental or legal permission is different throughout societies, and not necessarily related to of development level. For instance, in Brazil, just like

\footnotetext{
${ }^{1}$ Economista, Mestra em Educação Comparada, Doutora em Demografia. Pesquisadora Bolsista de Pós-Doutorado no International Institute for Applied Systems Analysis (IIASA, Austria) e Pesquisadora do Wittgenstein Centre for Demography and Global Human Capital. Profa. do Depto. de Economia da UFPR. raquel.guimaraes@ufpr.br ${ }^{2}$ Economista, Mestra em Desenvolvimento Econômico pela Universidade Federal do Paraná. Doutoranda em Economia pelo Centro de Desenvolvimento e Planejamento Regional da UFMG.

${ }^{3}$ Economista, Mestra em Desenvolvimento Econômico na modalidade Profissional com ênfase no papel da inovação para o Desenvolvimento Econômico.
} 
in Japan, Chile, in the United Kingdom, in Honduras, Mozambique, among others, the minimum allowed age for marriage is 16 years for girls. In South Africa, Afghanistan, Canada and in the United States ${ }^{4}$, the minimum age is of 15 years. Colombia and Uruguay, on their turn, allow marriage with consent as soon as when a person reaches 12 years of age. There are also the countries where there is no minimum legal age for marriage, such as Sri Lanka and Saudi Arabia (WORLD POLICY ANALYSIS CENTER, 2017) ${ }^{5}$.

Although the definition of child marriage encompasses both genders, girls are considerably more affected by this practice. According to the UNICEF data, in 2013, over 700 million women all over the world got married before reaching 18 years of age, and about 250 million got married before reaching 15 years of age, one out of every three. For men, the estimates at hand reveal that 156 million got married before reaching 18 years, and 33 million before reaching 15 years (UNICEF, 2014; GIRLS NOT BRIDES, 2016). Despite national laws and international agreements prohibiting early marriage, this practice is present virtually all over the word, including, although in a lesser degree, the developed countries, such as those of western and eastern Europe, and industrialized countries, being also a recurring practice in Latin American countries (WRLD BANK, 2015; UNICEF, 2014; GIRLS NOT BRIDES, 2016). The sub-Saharan Africa and the south of Asia are areas with a particularly high prevalence of child marriage, where $50-70 \%$ of women got married or in a stable relationship with their partner before 18 years of age. On its turn, this number reaches 10-20\% in Latin America and Eastern Europe (RAJ, 2015; UNICEF, 2009). It should be considered, however, to which degree social norms and cultural, as well as local specificities of each area play a role in this phenomenon, there being the need, therefore, to adequately enumerate these factors in order to reach a better understanding of the reality of child marriage within different backgrounds.

In some countries, especially in Asian societies, child marriage may occur because of economic interests and needs. In these regions, there is still the custom of paying dowries for the marriage - a monetary transaction that takes place between the marrying parties' families. In some countries, the fiancé must offer an amount of money to the bride's family, and the younger the bride, the more expensive the dowry should be (PARSONS et al., 2015). In countries such as Somalia and the Republic of Kazakhstan, the factors determining child marriage are strongly rooted in the background of sexual violence and kidnapping of children

\footnotetext{
${ }^{4}$ It is important to point out that, in the United States, the laws setting up the minimum age for marriage are defined at the state level, and there are differences between the states.

${ }^{5}$ Access:https://www.worldpolicycenter.org/policies/what-is-the-minimum-age-of-marriage-for-girls-withparental-consent in order to see a world map and find information on the legal situation of each country.
} 
and adolescents. Early marriage in these regions represents a form of protection of girls against eventual attacks, even though, if they are abused, they must marry their aggressors in order to preserve the family's "honor" (TASCÓN et al., 2016).

Even though this is not a reality in other parts of the world, child marriage is not confined to these regions, that is, it exists in other countries, where there is no ritualizing and formalization of child marriage. Besides correlating the girls' existence with their vulnerability and poverty, as will be done up ahead, it is necessary to ponder upon the role of the girls' motivation - the internal desire or preferences that lead to action - and agency - the capacity of individual action - in the process of child marriage (LE GRAND, 2003). Thus, some girls perceive marriage as a possibility of escaping familiar conflicts; as an expression of independence and freedom by means of leaving their original home; as a way of experiencing a socially respected form of love, or even as a way of escaping socioeconomic vulnerability or an unwanted pregnancy (TAYLOR et al., 2015; TASCÓN et al., 2016; KNAUTH et al., 2006). In this sense, as exposed by the Montevideo Agreement ${ }^{6}$, young people must be recognized as subjects of law, and their progressive autonomy over their body and sexuality must be respected. However, the extreme poverty background and the high vulnerability of a large portion of girls that choose an early stable relationship challenge the understanding of true available choices (TAYLOR et al., 2015).

Having in mind the correlation between vulnerability and child marriage, the consequences of an early stable relationship for girls must be considered, whether they be formal or informal, which translate into anticipation of adulthood and limitation of rights while they are still children or adolescents (HERNÁNDEZ, GARCÍA, SUÁREZ, 2015). The literature highlights the presence of negative externalities to early stable relationships for the adolescents themselves and for society as a whole, starting from the low rates of schooling and literacy (FIELD; AMBRUS, 2008); low participation in the workforce (DAHLI, 2010); increase of fertility throughout a life cycle (RAJ et al., 2009); loss of autonomy and decreased power of decision (YOUNT; CRANDALL; CHEONG, 2018); increased chance of exposition to domestic violence, resulting in worse indicators of physical and psychological health (LE STRAT; DUBERTRET; LE FOLL, 2011). Besides, given the consequences listed above, it is likely that these girls, along with their future families, should find themselves in vulnerable situations, thus replicating the intergenerational poverty cycle (NGUYEN et al., 2012).

\footnotetext{
${ }^{6}$ See: https://www.cepal.org/celade/noticias/documentosdetrabajo/8/50708/2013-595-consenso montevideo pyd.pdf.
} 
In Brazil, according to the data of the demographic census tabbed by the authors (IBGE, 2010), 88,558 Brazilian children and adolescents aged between 10 and 14 lived in marital union in $2010,74 \%$ of them being girls, and $26 \%$ boys. For the age group from 15 to 17 years old, 567,378 married adolescents were observed, $86 \%$ of them female, and $14 \%$ male. As to the nature of the marital union among children and adolescents from 10 to 14 years, it has been observed that $12 \%$ of them have happened by means of a formal marriage (civil and religious marriage, or else only civil marriage), and $88 \%$ by means of informal marriage (only religious marriage or consented union). The same informality pattern may be observed for the age group of 15 to 17 years, in which $10 \%$ of the marriages were formal, and $90 \%$ informal. The consequences for human development, however, tend to be different for both groups, being harsher the earlier the commitment is made (NGUYEN et al., 2012).

In a study about the determinants of informal marriage in Brazil, Greene and Rao (1995) point out that the age difference between husband and wife was bigger in informal unions than in official ones. Other factors, such as early pregnancy, low level of education, living in a rural area, and being outside the workforce have an impact over the choice for this kind of marriage. Furthermore, the results indicate a more spread-out prevalence of informal marriages in the North region, followed by the Northeast and Central-West, which, according to the authors, reflect a historically special distribution of racial groups and socioeconomic status throughout the country.

Instituto Promundo, in a partnership with the Ford Foundation, the federal University of Pará, and Plan International Brazil, has recently conducted a research titled "She goes in my boat: marriage during childhood and adolescence in Brazil”. Its purpose was making an assessment of the determining factors of child marriage ${ }^{7}$ in two of the Brazilian states with greater prevalence: Pará, in the North region, and Maranhão, in the Northeast region. It is a qualitative research in which interviews were sought after, the subjects being girls aged between 12 and 18 in a marriage with older men ( 24 years or more); men aged from 24 to 60 years in a marriage with underage girls; family members (usually the party that bears responsibility for the girls, such as the father, mother, or grandparents); and professionals from the network of protection of children and adolescents. It has been determined that the relationships are primarily informal, and the beginning of marital life is strongly related to the age of the first pregnancy, 15 years, on average. The main factors related to an early marriage are: undesired

\footnotetext{
${ }^{7}$ The authors have defined child marriage as the marriage, formal or informal, involving boys or girls younger than 18 years of age.
} 
pregnancy; the parents' wish to control the teenagers' sex life; relief from poverty (upon relating to partners that give them the minimum of financial security); self-affirmation of individuality and freedom on the girls' part; and the search of men for younger girls for a relationship.

Although the number of child marriages is high - encompassing both officially formalized marriages and informal marriages before 18 years of age - in Brazil and over the world, studies about this practice focus mostly on low-income countries, known for ritualization around this practice. The goal of this study is to perform a synthesis of the literature about the microeconomic impacts of child marriage over selected dimensions of human development, namely education, labor market, health, fertility, violence, and women's empowerment. The choice of these indicators occurred through the convenience of factors frequently reported by studies in the area. The goal is to report on economic and social consequences of child marriage, drawing attention to a pertaining matter, although little explored within the country.

\section{METHOD}

This study methodology was raised from a bibliographic and documental review. The studies have been selected according to quality and relevance. National and international articles published in journals have been used, as well as international agencies and nongovernmental organizations that incorporate this agenda frequently to their programs. The preliminary selection of the articles has been made through the SciELO repository (Scientific Eletronic Library Online), through CAPES/MEC's Portal Periódicos, and through EconLit (American Economic Association). The search for the term "casamento infantil", in Portuguese, has showed no results in none of the three research sources. Therefore, a choice was made for searching for the English term, "child marriage", which has returned the following results: SciELO (7); EconLit (17); CAPES/MEC journals (2.531). Aiming at measuring the impacts of child marriage upon human development, the search has been refined by the terms "child marriage" and each one of the analyzed factors (Ex.: "child marriage", "education"). After assessment of the summaries, 46 works that contributed explicitly to the problem of the research were selected according to each of the analyzed factors. Most of the studies reflect case studies of specific countries, especially developing countries and countries located in the sub-saharan region and in the South of Asia, where there is a bigger rate of child marriage. A choice for the inclusion of relevant national and international works related to the theme has 
also been made; however, their identification factors are different (e.g. "sexual behavior" “interpersonal relationships").

Six ways through which the practice of child marriage or early stable union negatively affects Human Developed have been identified. They are: 1. Low levels of education and dropout rate; 2. Reduction of labor supply; 3 . Increase of the fertility rate; 4 . Worsening of health results; 5. Domestic violence; 6. Women's disempowerment. It is important to highlight that these transmission channels have mutually reinforcing effects, contributing as a whole to the intergenerational poverty cycle. Figure 1 represents the conceptual framework that maps these relationships, which will be explored in the following sections.

Figure 1 - Consequences of child marriage for Human Development

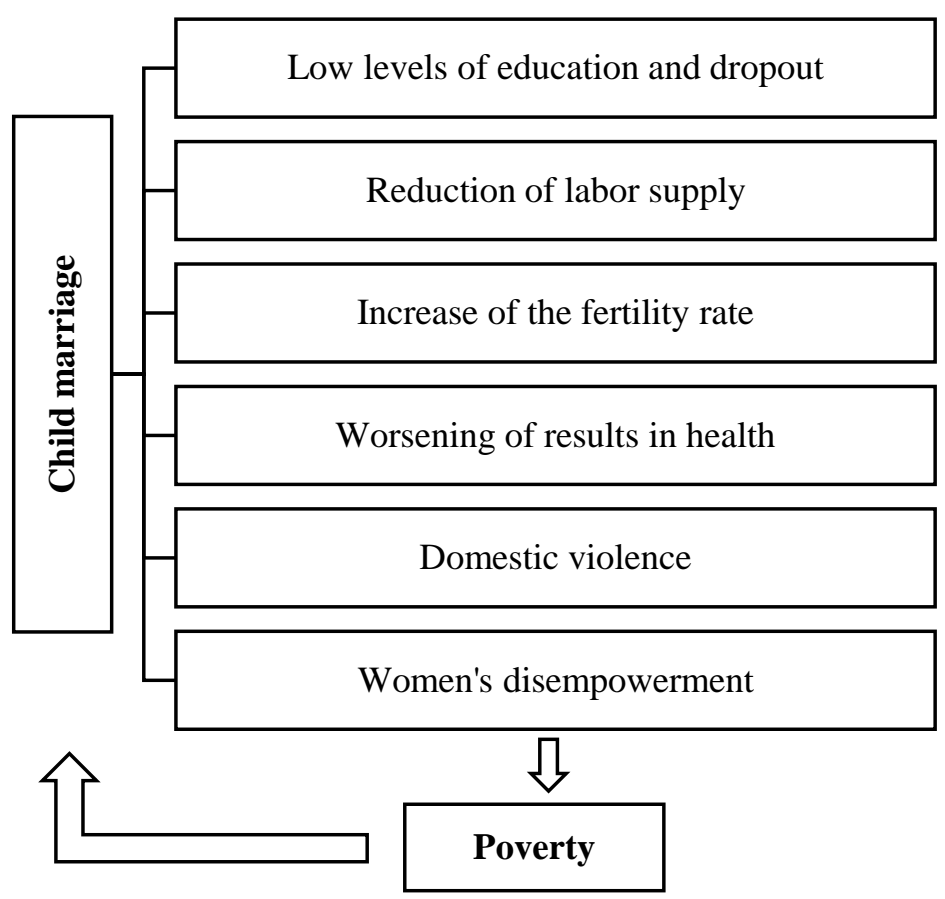

Source: Prepared by the authors.

Documented below are the findings on the literature about the impacts of early marriage over each of the dimensions of human development previously listed.

\section{Child marriage and educational results}

There are many factors leading girls to abandon school in their adolescence. These factors may be understood on a macro and social level as well as on a micro and interpersonal level. On the macro and social level, we have as an example the regional and cultural barriers, 
related to the background where these young girls come from. In some regions or communities, especially on those with high poverty levels, education is given little value by the general population, representing a barrier to the continuation of studies. The low quality of teaching, as well as the difficulty of access in many regions, represent as well a social and economic barrier to schooling (BHAGAVATHEESWARAN et al., 2016).

On the other hand, on the micro and interpersonal levels, there should be highlighted lack of family support, economic costs, non-valuing of education by the girls themselves, frequently accompanied by lack of perspectives, pregnancy during the adolescence, and early marriage (BHAGAVATHEESWARAN et al., 2016). However, giving these girls the opportunity to finish their studies, thus developing their abilities and capabilities, becomes a preventive factor for early union or child marriage (KAUSHIK; KAUSHIK; KAUSHIK, 2006; SMITH; STONE; KAHANDO, 2012). This is the reason why identifying the effects of child marriage on the educational results is not a trivial task due to its simultaneity: Girls get married younger because they are not in school or are they not in school because they get married earlier?

In some societies, cultural rules and values that relate the low schooling of the girls to early union prevail. For instance, the custom of marrying in face of a payment, which may or may not be a monetary value previously agreed upon between the engaged parties' families. This transaction may occur in several ways, but are typically defined in two categories: transfers from the groom's family to that of the bride (bride price) and transfer from the bride's family to that of the groom (dowry). China is a classic example in which both systems currently coexist, especially in rural areas; whereas the bride price is a tradition that is stronger in northern regions of Africa, the dowry occurs mainly in India and other countries in the Asian South. In Brazil and Mexico, the dowry practice was common during the colonial period, but was extinguished later on (ANDERSON, 2007). Both customs warp all incentives to the education of girls, since the younger and least schooled, the cheaper the transaction, thus enforcing gender discrimination among children in these families (ANDERSON, 2007; SMITH; STONE; KAHANDO, 2012; RAJ, 2010; WODON; NGUYEN; TSIMPO, 2016).

Regarding expectations, difficulty in labor market integration associated with low productivity reduces efforts toward completing the regular educational pathway (PARSONS et al., 2015). The idea behind this fact is that girls often grow up hearing that it is not worth to invest in education, since their social role is to raise a family and to take care of their home and children (TAYLOR et al., 2015). The absence of women in leadership positions contributes to 
this, which reinforces the stigma according to which investing in education for girls does not pay off, for the career choices are limited (BEAMAN et al., 2012). Furthermore, belief in the stereotype according to which boys perform better at school reinforces gender discrimination within private homes, leading parents to invest in the boys' education in detriment to that of the girls (WONDON; NGUYEN; TSIMPO, 2016).

Early unplanned pregnancy also shows up as an important factor to school dropout, although it is often the cause and consequence of early union. When pregnancy is not the very reason for marriage, the birth of the first child typically coincides with it (TAYLOR et al., 2015; LIMA, 2018). The consequences of pregnancy during adolescence over education are immediate and change the entire life course. The unfavorable socio-economic profile of these adolescent mothers makes the first consequence leaving the schooling behind in order to take on the responsibility of taking care of the children, especially due to the lack of social and familiar support.

Field and Ambrus (2008) have explored the hypothesis that girls drop out of schools in Bangladesh due to marriage or early union. According to the authors, for girls that are married, every additional year in marriage leads to a decrease of $4 \%$ to $6 \%$ on the likelihood of completing secondary school. On the other hand, every additional year in marriage may increase the likelihood of literacy by $5.6 \%$, and schooling by 0.22 years. Knauth et al. (2006) have also demonstrated that schooling, especially for women, is a key factor for postponing the union between young people in the case of Brazil. Besides the girls' education, Smith, Stone, and Kahando (2012) have also highlighted the importance of mother's education as a preventive factor to early union. According to the authors, when mothers have been schooled, whether formally or informally ${ }^{8}$, the acquired knowledge has a direct effect over the delay in the child marriage or the early union of their daughters. The mechanisms that govern this are connected to the increase in women empowerment, which increases capability of participating or influencing family decisions, contributing toward improving educational and health results for the children. These results are corroborated by Delprato; Akyeampong; Dunne (2017), who have investigated the effects of educational inequalities for children that are born from child marriage in over 20 countries of the sub-Saharan Africa.

\footnotetext{
${ }^{8}$ The authors define as informal schooling the literacy courses for adults, which differ in their core from the formal curricular structure, being important, however, for providing women a wide variety of functional items such as health, family planning, schooling importance, among others.
} 
The consequences of interruption of the educational pathway derived from early union over human development may be direct as well as indirect. From a direct standpoint, depriving a girl of learning opportunities limits the full development of her capabilities, influencing her perspective of finding a job and/or professional training, and, as a result, affecting her economic gains throughout life (KHANNA; VERMAN; WEISS, 2013). From an indirect standpoint, there is the increased difficulty of gaining access to information about health and well-being for the girls themselves and their children; limited access to knowledge about reproductive health, making them more exposed to sexually transmissible diseases and increase of fertility; women disempowerment, since that, for many girls, school is not only a space for formal and informal education, but also a social space where support networks are built, contributing to their mobility and engagement in subjects and activities pertaining to the community (PARSONS et al., 2015; ABDULLAH; QURESHI; QUAYES, 2015).

\section{Child marriage and labor market}

The relationship between child marriage and labor market may be construed in two ways: if, on the one hand, child marriage has a negative impact on participation and productivity of women in the workforce, on the other hand, lack of opportunity in the labor market has decisive effects on marriage, which is often regarded as "the best available option". Sviatschi (2013) has demonstrated that the expansion of opportunities in the labor market may be a key variable to postponing the decision of getting married or in an early union with the partner. In order to do this, the author has studied the growth of the free commerce zone of the Dominican Republic, and has found out that a larger participation of women in the workforce has provided a positive impact of 1.6 years over the age of the first marriage, and a decrease of $30 \%$ in child marriage.

On its turn, child marriage may influence the participation of women in the workforce in several ways. Three indirect channels through which this may happen are highlighted in the literature. The first channel corresponds to the high levels of capability and education of girls that get married early. The second channel is related to the gender rules that accompany child marriage, and determine the participation of women, almost exclusively, in unpaid domestic work. The third channel is related to the high rate of fertility and complications resulting from early pregnancy that may push women away from the labor market. 
The lack of opportunities in the labor market is mainly related to the low education of girls that get into an early marriage (GROWN; GUPTA; KES, 2005; PARSONS et al., 2015). To the extent that middle school and higher education are highly associated with participation in the workforce, but most girls that get married early do not reach these school levels (FIELD, AMBRUS, 2008), it is possible to predict that their participation in the workforce will be negatively affected. With reduced schooling, the capabilities required by formal work are affected, reducing their participation in the labor market (GROWN; GUPTA; KES, 2005; PARSONS et al., 2015).

Transition from childhood and adolescence to a "forced" adult life is accompanied and strongly influenced by traditional gender rules, which assign to women the role of caretakers and party responsible for the domestic work (TAYLOR et al., 2015). Thus, upon getting into an early marriage, girls are led to unpaid domestic work, generating negative effects over decisions of participation in the workforce. These barriers are particularly verifiable during the early stages of marriage and family formation, and are stronger the greater the age difference between wife and husband is (PARSONS et al., 2015). Furthermore, isolation from social coexistence and lack of mobility may keep them from access to markets and formal work opportunities (UNFPA, 2012).

Another aggravating child marriage-related factor that limits the participation of women in the workforce is the high fertility rate. The age at the first marriage is strongly related to early pregnancy (TAYLOR et al., 2015), which makes the girls take more responsibility wen taking care of the children, resulting in school drop-out, with negative consequences over the labor market (DAHL, 2010). Besides, early pregnancy-related issues with the mother's health generate larger risks of complications and child mortality (NOUR, 2009). For those who survive severe complications upon giving birth, a long period of physical and psychological recovery is required, with its social and economic consequences.

The impacts over human and economic development may be translated individually as well as collectively. The lack of engagement in the labor market may, for instance, increase poverty in private homes, expose individuals to a greater economic vulnerability due to occasional negative income impacts, reduce diversification of family income, and change incentives regarding resource allocation for short-term investments in detriment to long-term investments in physical and human capital. Besides, a greater vulnerability of families may have intergenerational impacts, with long-term implications that might increase poverty on the 
collective level, contributing negatively to the development and the economic growth of communities (PARSONS et al., 2015).

\section{Child marriage and health results}

Child marriage or early union have a negative impact on several health results. Although a majority of studies tends to focus on negative impacts over sexual and reproductive health, marital life during adolescence is also associated to higher rates of mental disorders such as depression and suicide, as well as physical illness, such as poor nutrition and malaria (LE STRAT; DUBERTRET; LE FOLL, 2011; PARSONS et al., 2015). Whereas mental health is affected mainly due to isolation and episodes of domestic violence, physical illness usually results from poverty in the home or else of gender rules prevailing on the domestic environment and acting unfavorably over the female gender.

School is usually the main means of communication about preventive actions and health promotion for children and adolescents. The differences in schooling according to age in the first marriage and/or ceasing of studies in the beginning of the marriage or union contribute to the disadvantage of information about health (LE STRAT; DUBERTRET; LE FOLL, 2011). In a general way, upon having an early start of marital life, girls tend to move away from friendship bonds and communal activities, thus leading a rather solitary life, restricted to the domestic environment, and occupying themselves most of the time with new responsibilities of adult life, such as taking care of home and children, since the birth of the first child is strongly related to the age of the first marriage (TAYLOR et al., 2015).

The result of isolation from social coexistence, often alongside episodes of domestic violence, is the development of mental disorders, such as anxiety and depression, which may lead to suicide in the most severe cases (RAJ, 2010; LE STRAT; DUBERTRET; LE FOLL, 2011; GAGE, 2013). In a study about the negative effects of child marriage ${ }^{9}$ on the mental health of women in the United States, Le Strat; Dubertret; Le Foll (2011) have showed that women married before turning 18 are more likely to develop depression, anxiety, and to become addicted to tobacco when compared to women that got married as adults.

\footnotetext{
${ }^{9}$ The authors have defined child marriage as the formal or informal union before 18 years of age. The study sample had 24,254 women aged 18 or more. From the total of women, $76.87 \%(18,645)$ were married, and from these, $11.69 \%$ (2,181) got married before completing 18 years: 51,5\% (1.124) aged 16 or less, and 12,09\% (136 out of $1.124)$ at 14 years. Using the complex sample design, the authors highlight that these numbers correspond to the national population of: 9.406 .523 women that got married at 16 years or less, and 1.688 .752 women that got married at 15 years or less.
} 
The girls that got an early marriage are also more exposed to sexually transmissible diseases (RAJ, 2010; RAJ; BOEHMER, 2013). One of the main difficulties of child marriage, even when consented, is the financial and emotional dependency in which the girls find themselves, giving room to psychological abuse and excessive controls on the husbands' part. Men are mostly older and have some sexual experience, having multiple partners throughout life. Aware of the dangers concerning sexually transmissible diseases, they look for younger, virgin girls, who are not likely to be contaminated, with whom to get married. To the extent that girls are incapable of negotiating safe sex with their partner, the risk of catching a sexually transmissible disease such as AIDS/HIV is substantially increased (UNFPA, 2012; NOUR, 2009).

The complications resulting from early pregnancy are also risk factors for the girls' health. A direct result is the increase in the number of labor-related deaths: pregnancy and childbirth complications are the second leading cause of death for girls aged between 15 and 19 worldwide (UNFPA, 2013). The leading causes of maternal mortality include eclampsia ${ }^{10}$, postpartum hemorrhage, HIV virus infection, malaria, and obstruction of labor due to shoulder dystocia - a common case especially when a girl's body is not mature enough to host a pregnancy. Another recurring disease is cervical cancer, caused mainly by early sexual initiation and by the human papilloma virus, better known as HPV (NOUR, 2009; RAJ, 2010; GODHA; HOTCHKISS; GAGE, 2013; NOUR, 2006).

Physical diseases are closely related to the poverty of homes. In India, for instance, the nutritional condition of girls, poor at first, might get worse after marriage due to the social position occupied by the young brides, or else to local gender rules that impair them (HAMPTON, 2010). The consequences of poor nutrition have an impact not only over the girls' health, but also over the health of children, who become more vulnerable to child mortality and low weight at birth (PARSONS et al., 2015; NOUR, 2009; RAJ et al., 2010). Both mothers and sons/daughters become less productive throughout life, perpetuating the vicious cycle of poverty. The weakening of the immune system at pregnancy also increases the risk of catching infectious diseases such as malaria (NOUR, 2009).

The worst health results have direct and indirect impacts on human development. In a direct way, negative impacts on health change the destiny of domestic resources, increasing generally unforeseen expenses with medication and health care, which leaves these families in an even more vulnerable situation. Besides, impacts may also happen indirectly, through the

\footnotetext{
${ }^{10}$ Arterial hypertension-related convulsions during pregnancy.
} 
reduction of income and productivity due to poor health conditions, thus reducing future income. Intergenerational effects upon the physical and mental health of children must be highlighted as well. Beyond physical health problems, such as low weight at birth, impaired immune system, and poor nutrition, among others, the effect of exposing children and adolescents to violence situations are immediate and last in the long term, affecting all of the child's life cycle, including school performance (PARSONS et al., 2015; RAJ et al., 2010).

\section{Child marriage and Fertility}

The increase in the fertility rate - an estimate of the number of children throughout life - among women that get married or in a union with their partners at young age is frequently reported as an adverse effect of child marriage (NASRULLAH, 2014; RAJ et al., 2009). According to the United Nations Population Fund, approximately 16 million girls aged between 15 and 19 give birth every year in developing countries. In nine out of ten cases, the adolescent mother is married (UNFPA, 2012). Child marriage has negative impacts over the number of children, the health interval between pregnancies, and, as a result, over the results of maternal health as the spontaneous termination of pregnancy (NASRULLAH et al., 2014). In this way, forestalling child marriage means reducing adverse effects on early pregnancy and its related risks (UNFPA, 2012).

The reasoning behind high fertility in child marriage range from cultural pressure, such as the need for girls to prove their fertility, thus ensuring their identity, status, and earning respect as an adult; the husband's wish to have more children, and the preference for male children; the high child mortality and the regard for children as workforce; agency problems within homes, where girls have low, if any, negotiation power; and lack of information and/or access to contraceptive methods.

Adolescence is characterized by a transition stage from childhood to adult life, marked by physical, psychological, and behavioral changes, as well as by the development of sexuality. Doubts about their fertility, often alongside pressure from the husband, especially when a dowry must be paid, lead girls to try to "prove it" as soon as they get married (NOUR, 2006). The need to prove their fertility comes not only as a physiological ordeal for the body, but also as a need for representation of the gender social role, since, in the social construct, maternity is seen as a "natural" experience for the feminine gender, a consequence of biologic predisposition. Being a mother becomes part of the construction of these girls' identities. 
Poverty is also a determining factor for the increase of fertility in private homes. One of the identified causes for the high demand on the part of the families in underdeveloped countries is the generational "agreement" about the ways through which obligations and rewards are distributed among generations. Children begin to work as soon as they are able to do it, and dedicate themselves throughout life to taking care of their parents until old age. Thus, the lack of children may be understood as a deprivation of assets, putting at risk the possibility of getting care and financial health by the end of one's life (ESWARAN, 2006; DELPRATO et al., 2015). Furthermore, the high child mortality rate that expose children to a considerable risk increases the number of desired children on the part of families as a means of "compensation" to prematurely dead children, who will not be able to contribute to the generational "agreement" (ESWARAN, 2006).

Gender discrimination within private homes also reinforces the increase in fertility to the extent that several attempts are made until a male child is born (NASRULLAH et al., 2014). This is because men are seen as natural heirs to their fathers, often remaining in the familiar environment with their new family and contributing to the support of the private home throughout life, whereas girls are expected to follow their husband's steps, benefiting their husband's families, rather than their own, with investments made in them (WODON et al., 2016).

The lack of agency of girls within marriage makes them have little or no control over their sexual or reproductive life. Contrarily to the freedom that was desired and projected upon marriage, when consented, what is witnessed in these private homes is a highly unequal power relationship. For instance, married girls rarely have any say on family planning at all. The practice of "coitus interruptus" is frequently employed among couples, diminishing usage of condoms, and, as a result, increasing the chances of pregnancy (TAYLOR et al., 2015). Furthermore, the lack of information and/or access to contraceptive methods also contribute to the increase in fertility (RAJ et al., 2009; UNFPA, 2012).

The consequences of a higher fertility rate are a result of the increase in poverty at private homes, resulting in worse health results for mothers and children. Attention must be drawn upon the importance of family planning, which may contribute to the reduction of fertility. At the same time, it should be recognized the success of this policy depends upon several factors, ranging from political support to the demystification of methods and cultural acceptance in some regions, the role of information diffusion being fundamental in apparently disfavored social and cultural backgrounds. Besides bringing benefits for the health of young 
mothers, reducing the proportion of children within particular homes allows for a "relief" on expenditures with the children's health and education, thus perpetuating a virtuous cycle.

\section{Child marriage and domestic violence}

Child marriage or early union, on their own, can be regarded as a form of violence, to the extent that they contribute negatively to the physical, mental, and emotional development of girls. There are many kinds of violence practiced by the partners; violent behaviors may take on the form of physical aggression, ranging from psychological attacks to threatening behaviors, forced sexual activity, and rape (JAMABO, 2012). All of them, collectively or individually, have severe negative effects over the physical and mental condition of the girls, including their reproductive health (PARSONS et al., 2015; NASRULLAH; ZAKAR; ZAKAR, 2014).

Domestic violence within marriage is a direct reflex of institutionalized masculine dominance in some societies. Due to the hierarchic relationship established between genders, men have a feeling of ownership over their wives' life, which makes them feel entitled to make use of physical or psychological violence in order to impose their will and punish any kind of behavior they might consider socially inadequate COURTENAY, 2000). Jayachandran (2015) presents some stylized facts about gender gaps and economic development, showing that the proportion of people who agree with the sentence: "Giving your wife a beating is justifiable if she goes out without giving notice and there is an argument", used as proxy for average tolerance to gender violence within the population, varies from $1 \%$ to $85 \%$ between countries, being superior in poor countries.

Girls that get married early, whether this union be formal or informal, are more given to believing that some episodes of violence are acceptable - for instance, the aforementioned situation -, and are, therefore, more subject to experiencing these situations throughout life (JAMABO, 2012). There is still an aggravating factor regarding the frequency of these occurrences when the age difference between the girl and the partner is too big (UNICEF, 2014). Emotional and financial dependency, often accompanied by lack of family support, limit the girls' alternatives for abandoning the background in which they suffer aggressions (PARSONS et al., 2015; YOUNT et al., 2016; JAMABO, 2012). Besides, from the feminine standpoint, marriage represents social prestige, being part of the construction of an identity. 
Thus, girls can internalize patriarchy's social rules, naturalizing the dominant behavior, oftentimes aggressive, of men, in order to stay in a relationship (YOUNT et al., 2016).

Child marriage also increases the probability of domestic violence through disempowerment throughout women's life course. Girls who get into an early marriage tend to leave school early and, as a result, find greater difficulty in being allocated in the labor market, have little economic resources, and are generally pulled away from social coexistence. Given these circumstances, young brides tend to have a lower level of self-esteem and self-efficacy, becoming more vulnerable, for instance, to psychological violence practiced by their partners (TAYLOR et al., 2015; CRANDALL et al., 2016).

The absence of law-supported protective measures also contributes to the increase of domestic violence, making physical and sexual abuse performed by the partners one of the most complex subjects within the scope of child marriage. This is because marriage ends up corroborating with the false idea of implicit consent of the victim to the sexual act. Despite the advancements in the marital rape explicit criminalization law, especially in developed countries, there are still economies where this kind of disposition does not exist. In the Middle East and in North Africa, for instance, only Malta has laws against rape inside marriage. Besides, in many regions, the so-called exemptions from rape law still exist, the right to initiate criminal action against husbands being forbidden to women (WORLD BANK, 2017).

The consequences of violence against girls over human development may be direct as well as indirect. In a direct way, negative impacts are reflected upon education of physical and emotional well-being from damages caused to physical and mental health, such as bodily injury, chronic pain, gastrointestinal disorders, gynecological problems, including sexually transmissible diseases, depression, and post-traumatic stress (NASRULLAH; ZAKAR; ZAKAR, 2014). As a result, family investments are oftentimes altered, increasing unforeseen expenses with health care (PARSONS, et al., 2015). In an indirect way, mobility deprivation under physical and emotional constraints has consequences over income and productivity, as well as other negative consequences caused by isolation (e.g. lack of information) (NASRULLAH; ZAKAR; ZAKAR, 2014). Besides, the effects may also be experienced by future generations, having negative impacts over health and education, and reinforcing the acceptability of violence (PARSONS et al., 2015).

\section{Child marriage and feminine empowerment}


Feminine empowerment may be understood as the development of human, social, and economic resources that might allow women to take some individual power and conquer spaces upon making decisions (CRANDALL et al., 2016; YOUNT; CRANDALL; CHEONG, 2018). "Goal No. 5" of the 17 Sustainable Development Goals ${ }^{11}$ elaborated by the United Nations (UN) is Gender Equality and Feminine Empowerment. Within this goal, eliminating the practice of early, forced, and child marriage is a condition for gender equality and feminine empowerment. This is because marriage during adolescence limits educational abilities, financial resources, as well as the mobility and autonomy of the girls, these being regarded as necessary elements for them to be able to define and reach goals of their own (NASRULLAH; ZAKAR; ZAKAR, 2014; WODON et al., 2016).

The literature documents that the age at the first marriage is a determining factor for the decline of the agency of the girls after a union (BUCHMANN, 2017). There are two main reasons for the association of these factors: low education and lack of economic resources, which limit the bargaining power of women within private homes (FIELD; AMBRUS, 2008). Due to the low level of education, girls are seen by their husbands as incapable of managing or taking financial decisions within the family environment (PARSONS et al., 2015; YOUNT; CRANDALL; CHEONG, 2018). Even among those that perform some kind of remunerated activity, there is rarely control on the part of girls over the perceived income (PARSONS et al., 2015). There are also losses of gains related to not entering the labor market or else quitting it because of premature marriage (DAHLI, 2010).

The cultural grounds on which marriages occur, based on the supremacy of the masculine figure as the male breadwinner, leaving women with the role of good wife and mother, reinforces the absence of women autonomy and reduces the participating voice of the girls in public spaces. A highly unequal power relationship is thus established within private homes, with control over the freedom of expression and decision-taking of young wives on the part of the husband (DESAI, ANDRIST, 2010; SPIERINGS et al., 2010). Furthermore, domestic chores are delegated to girls, making them unable to engage in other activities and develop their abilities (PEARSONS et al., 2015).

These relationships sometimes must be characterized as abusive relationships, since men aim to marry younger girls, who, according to masculine thinking, are easier to control (TAYLOR et al., 2015). Thus, as soon as they are married, men feel entitled to control their wives' access to and participation in social environments, implementing a patriarchal

\footnotetext{
${ }^{11}$ See the complete version at https://nacoesunidas.org/pos2015/agenda2030/
} 
relationship model. This power relationship is further intensified when there is the component of age difference between wife and husband. Thus, an isolated environment is created around these girls, who see themselves with no alternatives or support to develop their autonomy, keeping them restricted, for instance, to health information, education, family planning, sexual activity, among others (PARSONS et al., 2015; DUFLO, 2011).

The disempowerment of girls affects human development negatively through negative effects over their physical and emotional health, which often may unleash depression symptoms due to the low levels of self-esteem, self-control and lack of confidence in oneself, in many cases leading them to believe they are incapable of transforming their own lives; through interruption of the process of acquiring human resources, such as education, general knowledge, and personal abilities, construction of support networks, sense of right and mobility. Another condition is the limitation to access and control of the financial means (YOUNT; CRANDALL; CHEONG, 2018). Besides, feminine disempowerment can also have effects on the domestic environment through the decrease in well-being of the girls themselves and the low investment in the children's health and education, since empowered women have greater mobility, which resonates in the transformation of public spaces through investments in social and infrastructure services (DUFLO, 2011).

\section{Summary of Literature}

The causes for child marriage or early union have economic, cultural, and social aspects, which are frequently related. Chart 1 presents a summary of the main channels through which child marriage negatively affects human development, such as mentioned in the previous chapters.

Chart 1 - Summary of the transmission channels through which child marriage affects Human Development Indexes

\begin{tabular}{|c|c|c|}
\hline $\begin{array}{l}\text { Human Development } \\
\text { Indexes }\end{array}$ & $\begin{array}{c}\text { Transmission channels of the way child } \\
\text { marriage affects indexes }\end{array}$ & Source \\
\hline \multirow[b]{3}{*}{ Educational results } & $\begin{array}{l}\text { Macro and social-level factors: regional and } \\
\text { cultural barriers, low recovery and quality of } \\
\text { studies in some locations. }\end{array}$ & Bhagavatheeswaran et al. (2016) \\
\hline & $\begin{array}{l}\text { Micro and interpersonal factors: lack of } \\
\text { family support, economic costs and lack of } \\
\text { belief in return from education on the part of } \\
\text { girls themselves. }\end{array}$ & $\begin{array}{l}\text { Bhagavatheeswaran et al. (2016) } \\
\text { Kaushik; Kaushik; Kaushik. } \\
\text { (2006) } \\
\text { Smith; Stone; Kahando (2012) }\end{array}$ \\
\hline & $\begin{array}{l}\text { Cultural norms and values: dowry and bride } \\
\text { pricing, customary in some regions, warp } \\
\text { incentives to the girls' education. }\end{array}$ & $\begin{array}{l}\text { Anderson (2007) } \\
\text { Raj (2010) } \\
\text { Wodon; Nguyen; Tsimpo (2016) } \\
\text { Smith; Stone; Kahando (2012) }\end{array}$ \\
\hline
\end{tabular}




\begin{tabular}{|c|c|c|}
\hline & $\begin{array}{l}\text { Expectations: low expectations regarding } \\
\text { insertion in the labor market and low } \\
\text { productivity, as well as absence of women in } \\
\text { leadership positions reinforce the stigma } \\
\text { according to which investments in education } \\
\text { of girls are not justifiable. }\end{array}$ & $\begin{array}{l}\text { Parsons et al. (2015) } \\
\text { Taylor et al. (2015) } \\
\text { Beaman et al. (2012) } \\
\text { Wodon; Nguyen; Tsimpo (2016) }\end{array}$ \\
\hline & $\begin{array}{l}\text { Early pregnancy: The lack of social and } \\
\text { familiar support makes dropping out of } \\
\text { school its first consequence. }\end{array}$ & $\begin{array}{l}\text { Taylor et al. (2015) } \\
\text { Kanauth et al. (2006) } \\
\text { Lima (2018) }\end{array}$ \\
\hline & $\begin{array}{l}\text { Mothers' education: Better-educated mothers } \\
\text { have a greater capacity of participating in } \\
\text { family decisions or influencing them, } \\
\text { contributing to better educational results for } \\
\text { children. }\end{array}$ & $\begin{array}{l}\text { Delprato; Akyeampong; Dunne } \\
\text { (2017) }\end{array}$ \\
\hline \multirow{4}{*}{ Labor Market } & $\begin{array}{l}\text { Labor market opportunities the increase in } \\
\text { feminine participation in the workforce is a } \\
\text { key factor for the postponing of child } \\
\text { marriage. }\end{array}$ & Sviatschi (2013) \\
\hline & $\begin{array}{l}\text { Low levels of capabilities and schooling: the } \\
\text { lack of opportunities in the labor market is } \\
\text { mainly related to the low education of girls } \\
\text { that get into an early marriage. }\end{array}$ & $\begin{array}{l}\text { Grown; Gupta; Kes (2005) } \\
\text { Parsons et al. (2015) } \\
\text { Field e Ambrus (2008) }\end{array}$ \\
\hline & $\begin{array}{l}\text { Gender rules: girls are led to unpaid domestic } \\
\text { work, generating negative effects over } \\
\text { decisions of participation in the workforce. }\end{array}$ & $\begin{array}{l}\text { Taylor et al. (2015) } \\
\text { Parsons et al. (2015) } \\
\text { UNFPA (2012) }\end{array}$ \\
\hline & $\begin{array}{l}\text { Complications resulting from early } \\
\text { pregnancy: early pregnancy-related issues } \\
\text { with the mother's health generate larger risks } \\
\text { of complications and child mortality. }\end{array}$ & $\begin{array}{l}\text { Taylor et al. (2015) } \\
\text { Nour (2009) } \\
\text { Dahl (2010) }\end{array}$ \\
\hline \multirow[b]{3}{*}{ Health Results } & $\begin{array}{l}\text { Mental Health: mental diseases usually } \\
\text { develop due to isolation and the solitary life } \\
\text { these girls start living after marriage. }\end{array}$ & $\begin{array}{l}\text { Raj (2010) } \\
\text { Le Strat; Dubertret; Le Foll (2011) } \\
\text { Gage (2013) } \\
\text { Taylor et al. (2015) }\end{array}$ \\
\hline & $\begin{array}{l}\text { Sexual and reproductive health: girls are } \\
\text { incapable of negotiating safe sex with their } \\
\text { partner, which increases the risk of catching } \\
\text { sexually transmissible diseases such as } \\
\text { AIDS/HIV. }\end{array}$ & $\begin{array}{l}\text { Raj (2010) } \\
\text { Raj and Boehmer (2013) } \\
\text { Nour (2009) } \\
\text { UNFPA (2012) } \\
\text { UNFPA (2013) } \\
\text { Godha; Hotchkiss; Gage (2013) }\end{array}$ \\
\hline & $\begin{array}{l}\text { Physical Health: Physical diseases are closely } \\
\text { related to poverty in private homes, the most } \\
\text { common examples being poor nutrition and } \\
\text { malaria. It also affects future generations. }\end{array}$ & $\begin{array}{l}\text { Hampton (2010) } \\
\text { Parsons et al. (2015) } \\
\text { Nour (2009) } \\
\text { Raj et al. (2010) }\end{array}$ \\
\hline & $\begin{array}{l}\text { Cultural pressures: Doubts about their } \\
\text { fertility, often alongside pressure from the } \\
\text { husband, lead girls to try to "prove it" as soon } \\
\text { as they get married. }\end{array}$ & Nour (2009) \\
\hline & $\begin{array}{l}\text { Child mortality and viewing children as an } \\
\text { investment: Children begin to work as soon as } \\
\text { they are able to do it, and dedicate themselves } \\
\text { throughout life to taking care of their parents } \\
\text { until old age. }\end{array}$ & $\begin{array}{l}\text { Eswaran (2006) } \\
\text { Delprato (2015) }\end{array}$ \\
\hline
\end{tabular}




\begin{tabular}{|c|c|c|}
\hline \multirow[t]{2}{*}{ Fertility Rate } & $\begin{array}{l}\text { Preference for male children: gender } \\
\text { discrimination within private homes also } \\
\text { reinforce the increase in fertility to the extent } \\
\text { that several attempts are made until a male } \\
\text { child is born. }\end{array}$ & $\begin{array}{l}\text { Nasrullah et al. (2014) } \\
\text { Wodon; Nguyen; Tsimpo (2016) }\end{array}$ \\
\hline & $\begin{array}{l}\text { Agency problems inside private homes: } \\
\text { married girls rarely have any say on family } \\
\text { planning at all. }\end{array}$ & $\begin{array}{l}\text { Taylor et al. (2015) } \\
\text { Raj et al. (2009) } \\
\text { UNFPA (2012) }\end{array}$ \\
\hline \multirow{4}{*}{ Domestic Violence } & $\begin{array}{l}\text { Hierarchic relationship established between } \\
\text { genders: men have a feeling of ownership } \\
\text { over their wives' life, which makes them feel } \\
\text { entitled to make use of physical or } \\
\text { psychological violence in order to impose } \\
\text { their will. }\end{array}$ & $\begin{array}{l}\text { Courtenay (2000) } \\
\text { Jayachandran }(2015)\end{array}$ \\
\hline & $\begin{array}{l}\text { Construction of the feminine identity: girls } \\
\text { can internalize patriarchy's social rules, } \\
\text { naturalizing the dominant behavior, } \\
\text { oftentimes aggressive, of men, in order to } \\
\text { stay in a relationship. }\end{array}$ & $\begin{array}{l}\text { Jamabo (2012) } \\
\text { UNICEF (2014) } \\
\text { Parsons et al. (2015) } \\
\text { Yount et al. (2016) }\end{array}$ \\
\hline & $\begin{array}{l}\text { Women's disempowerment: the lack of social } \\
\text { and economic resources makes girls more } \\
\text { vulnerable to domestic violence. }\end{array}$ & $\begin{array}{l}\text { Taylor et al. (2015) } \\
\text { Crandall et al. (2016) }\end{array}$ \\
\hline & $\begin{array}{l}\text { Protective measures: The absence of } \\
\text { protective measures supported by law also } \\
\text { contributes to the increase in domestic } \\
\text { violence. }\end{array}$ & World Bank (2017) \\
\hline $\begin{array}{c}\text { Women's } \\
\text { Empowerment }\end{array}$ & $\begin{array}{l}\text { Agency and decision taking within private } \\
\text { homes: the lack of information, capabilities, } \\
\text { and support networks help increasing social } \\
\text { and economic isolation, reducing the girls' } \\
\text { agency. }\end{array}$ & $\begin{array}{l}\text { Field e Ambrus (2008) } \\
\text { Buchmann (2017) } \\
\text { Parsons et al. (2015) } \\
\text { Yount; Crandall; Cheong (2018) } \\
\text { Dahli (2010) } \\
\text { Desai and Andrist (2010) } \\
\text { Spierings et al. (2010) } \\
\text { Taylor et al. (2015) } \\
\text { Duflo (2011) }\end{array}$ \\
\hline
\end{tabular}

Source: Prepared by the authors.

\section{CONCLUSION}

Although the occurrence of child marriage has been decreasing through the past decades all over the world, this practice is still common and frequent in some countries, to the point of being supported by law (WONDON et al., 2017). One tends to consider marriage as a consented union between two individuals who choose to build a family together. However, when talking about child marriage, this is often a one-sided decision that may come either from the groom's or from the bride's family. Even when there is consent from both parties, that is, when the girl has expressed any level of agency about marriage, such as what happens in Brazil, where there is a prevalence of consented, informal marriages, it may be observed that these "marriages", on 
the part of the girls, is actually a combination of individual and structural factors producing nefarious consequences.

What may be concluded about the literature on this topic is that early marriage is deeply rooted in gender inequality and reflects discriminatory social rules about women's role within society. The parents' desire to control their children's and adolescents' sex life in order to preserve the honor of the family, the belief that women need a husband, the lack of economic perspective about the future of the girls, the poverty of private homes, all of these examples make marriage sound like a solution. However, it is documented that, upon marrying early, these children and adolescents end up perpetuating the poverty and inequality cycle, thus reinforcing gender inequalities.

One of the problems that emerge around child marriage is about the local background in which it develops. In some regions, this practice is widespread and normalized as to not be seen as a problem (TAYLOR et al., 2015). Giving the greater visibility of the theme, increasing debate and discussion is as important as creating/increasing life quality and well-being opportunities for these children. Although it is part of the "United Nations' 17 Sustainable Development Goals", little attention has been given to the causes and consequences of child marriage in the country (TAYLOR et al., 2015).

Starting from a systematic assessment of the efforts to discourage child marriage, the United Nations Population Fund (UNFPA) has identified five approaches to the fight against this practice, which, according to empirical evidence, have been presenting meaningful results. They are the following: 1. Empowering girls through the development of their abilities and increasing their support networks; 2. Improving access to formal and quality education; 3. Mobilizing the communities in order to modify cultural rules that affect girls negatively; 4. Improving the economic situation of the girls, as well as that of their families; and 5. Promoting favorable legal and political environments (UNFPA, 2012). Thus, this study has tried to raise debate and alert the population about the harms of the practice of child marriage or early union, persisting in many regions of the country.

\section{REFERENCES}

ABDULLAH, S.; QURESHI, H.; QUAYES, S. The adverse effect of child marriage on women's economic wellbeing in Bangladesh-can microfinance help?. The Journal of Developing Areas, v. 49, n. 4, p. 109-125, 2015. 
ANDERSON, S. The economics of dowry and bride price. The Journal of Economic Perspectives, v. 21, n. 4, p. 151-174, 2007.

BEAMAN, L. et al. Female leadership raises aspirations and educational attainment for girls: A policy experiment in India. science, v. 335, n. 6068, p. 582-586, 2012.

BHAGAVATHEESWARAN, L. et al. The barriers and enablers to education among scheduled caste and scheduled tribe adolescent girls in northern Karnataka, South India: A qualitative study. International journal of educational development, v. 49, p. 262-270, 2016.

BUCHMANN, N. et al. Power vs Money: Alternative Approaches to Reducing Child Marriage in Bangladesh, a Randomized Control Trial. 2017.

COURTENAY, W. H. Constructions of masculinity and their influence on men's well-being: a theory of gender and health. Social science \& medicine, v. 50, n. 10, p. 1385-1401, 2000.

CRANDALL, A. et al. Women's age at first marriage and post marital agency in Egypt. Social Science Research, v. 57, p. 148-160, 2016.

DAHL, G. B. Early teen marriage and future poverty. Demography, v. 47, n. 3, p. 689-718, 2010.

DELPRATO, M.; AKYEAMPONG, K.; DUNNE, M. Intergenerational education effects of early marriage in Sub-Saharan Africa. World Development, v. 91, p. 173-192, 2017.

DELPRATO, M. et al. On the impact of early marriage on schooling outcomes in SubSaharan Africa and South West Asia. International Journal of Educational Development, v. 44, p. 42-55, 2015.

DESAI, S.; ANDRIST, L. Gender scripts and age at marriage in India. Demography, v. 47, n. 3, p. 667-687, 2010.

DUFLO, E. Women's Empowerment and Economic Development. National Bureau of Economic Research, Cambridge, 2011.

ESWARAN, M. Fertility in developing countries. in: Banerjee, AV/Benabou, R./Mookherjee, D. Understanding Poverty, New Delhi et. al, p. 143-160, 2006.

FIELD, E.; AMBRUS, A. Early Marriage, Age of Menarche, and Female Schooling Attainment in Bangladesh. Journal of Political Economy, v. 116, n. 5, 2008.

GAGE, A. J. Association of child marriage with suicidal thoughts and attempts among adolescent girls in Ethiopia. Journal of Adolescent Health, v. 52, n. 5, p. 654-656, 2013.

GIRLS NOT BRIDES. It Takes a Movement: Reflecting on Five Years of Progress Towards Ending Child Marriage. Girls Not Brides, London, 2016. 
GODHA, D.; HOTCHKISS, D. R.; GAGE, A. J. Association between child marriage and reproductive health outcomes and service utilization: a multi-country study from South Asia. Journal of Adolescent Health, v. 52, n. 5, p. 552-558, 2013.

GROWN, C.; GUPTA, G. R.; KES, A. Taking Action: Achieving gender equality and empowering women. Earthscan, 2005.

HAMPTON, T. Child marriage threatens girls' health. Jama, v. 304, n. 5, p. 509-510, 2010.

HERNÁNDEZ, J.; GARCÍA, R.; SUÁREZ, R. Derechos humanos de las niñas y los niños y la prohibición del matrimonio infantil en los tratados internacionales. Tla-melaua, v. 9, n. 38, p. 140-160, 2015.

ISLAM, M. M. et al. Adolescent motherhood in Bangladesh: Trends and determinants. PloS one, v. 12, n. 11, p. e0188294, 2017.

JAMABO, T. A Discourse on the Developmental Effects of Child Marriage. African Journal of Social Sciences, 2(3): 135-44, 2012.

JAYACHANDRAN, S. The roots of gender inequality in developing countries. economics, v. 7, n. 1, p. 63-88, 2015.

KAUSHIK, S. K.; KAUSHIK, S.; KAUSHIK, S. How higher education in rural India helps human rights and entrepreneurship. Journal of Asian Economics, v. 17, n. 1, p. 29-34, 2006.

KNAUTH, D. R. et al. As trajetórias afetivo-sexuais: encontros, uniões e separação. In: O aprendizado da sexualidade: reprodução e trajetórias sociais de jovens brasileiros. 2006. p. 267-307.

LE STRAT, Y.; DUBERTRET, C.; LE FOLL, B. Child marriage in the United States and its association with mental health in women. Pediatrics, p. peds. 2011-0961, 2011.

LE GRAND, J. Motivation, agency, and public policy: of knights and knaves, pawns and queens. Oxford New York: Oxford University Press, 2003.

LIMA; S. B. C. M. The effects of child marriage and teenage pregnancy on girls' schooling: Evidence from Latin America. Comparative and International Education Society, 62nd Annual Conference. Mexico City, Mexico, 2018.

NASRULLAH, M. et al. Girl child marriage and its effect on fertility in Pakistan: findings from Pakistan Demographic and Health Survey, 2006-2007. Maternal and child health journal, v. 18, n. 3, p. 534-543, 2014.

NASRULLAH, M.; ZAKAR, R.; ZAKAR, M. Z. Child marriage and its associations with controlling behaviors and spousal violence against adolescent and young women in Pakistan. Journal of Adolescent Health, v. 55, n. 6, p. 804-809, 2014.

NGUYEN, M. C. et al. Measuring child marriage. Economics Bulletin, v. 32, n. 1, p. 398411, 2012. 
NOUR, N. M. Child Marriage: A Silent Health and Human Rights Issue. Review of Obstetric Gynecology, v. 2, p. 51-56, 2009.

NOUR, N. M. Health consequences of child marriage in Africa. Emerging infectious diseases, v. 12, n. 11, p. 1644, 2006.

PARSONS, J. et al. Economic Impacts of Child Marriage: A Review of the Literature. The Review of Faith \& International Affairs, v. 13, n. 3, p. 12-22, 2015.

SMITH, C. A.; STONE, R. P.; KAHANDO, S. A model of women's educational factors related to delaying girls' marriage. International Review of Education, v. 58, n. 4, p. 533 $555,2012$.

RAJ, A. When the mother is a child: the impact of child marriage on the health and human rights of girls, 2010.

RAJ, A.; BOEHMER, U. Girl child marriage and its association with national rates of HIV, maternal health, and infant mortality across 97 countries. Violence Against Women, v. 19, n. 4, p. 536-551, 2013.

RAJ, A. et al. Prevalence of child marriage and its effect on fertility and fertility-control outcomes of young women in India: a cross-sectional, observational study. The Lancet, v. 373, n. 9678, p. 1883-1889, 2009.

RAJ, A. et al. The effect of maternal child marriage on morbidity and mortality of children under 5 in India: cross sectional study of a nationally representative sample. BMJ, v. 340, p. b4258, 2010.

SPIERINGS, N. et al. Micro-and Macrolevel Determinants of Women's Employment in Six Arab Countries. Journal of Marriage and Family, v. 72, n. 5, p. 1391-1407, 2010.

SVIATSCHI, M. Too young to marry? Early marriage and labor demand. Mimeo, 2013.

TASCÓN, L. A. et al. Matrimonio infantil: Un problema social, económico y de salud pública. Revista chilena de obstetricia y ginecología, v. 81, n. 3, p. 254-261, 2016.

TAYLOR, A. et al. "She goes with me in my boat." Child and Adolescent Marriage in Brazil. Results from Mixed-Methods Research. Rio de Janeiro and Washington DC: Instituto Promundo, 2015.

UNITED NATIONS CHILDREN'S FUND (UNICEF). Child protection from violence, exploitation and abuse. 2017. Disponível em: https://www.unicef.org/protection/57929_58008.html. Acesso em: 18 de dez de 2017.

Ending Child Marriage: Progress and Prospects. UNICEF, New York, 2014.

The State of the World's Children: Maternal and Newborn Health. UNICEF, 2009.

Revista Desenvolvimento Socioeconômico em debate v.6 n.2 (2020) 
UNITED NATIONS POPULATION FUND (UNFPA). Marrying too young: End child marriage. UNFPA, New York, 2012.

Motherhood in Childhood: Facing the Challenge of Adolescent Pregnancy. UNFPA, New York, 2013.

WODON, Q; NGUYEN, M. C; TSIMPO, C. Child marriage, education, and agency in Uganda. Feminist Economics, v. 22, n. 1, p. 54-79, 2016.

WORLD BANK GROUP. Fechando a Brecha: Melhorando as Leis de proteção à Mulher Contra a Violência. WORLD BANK, 2015.

WORLD POLICY ANALYSIS CENTER. What is the minimum age for girls with parental consent?. Disponível em: https://www.worldpolicycenter.org/policies/what-is-the-minimumage-of-marriage-for-girls/what-is-the-minimum-age-of-marriage-for-girls-with-parentalconsent. Acesso em: $18 \mathrm{de} \mathrm{dez} \mathrm{de} 2017$.

YOUNT, K. M.; CRANDALL, A.; CHEONG, Y. F. Women's Age at First Marriage and Long-Term Economic Empowerment in Egypt. World Development, v. 102, p. 124-134, 2018.

YOUNT, K. M. et al. Child marriage and intimate partner violence in rural Bangladesh: a longitudinal multilevel analysis. Demography, v. 53, n. 6, p. 1821-1852, 2016. 